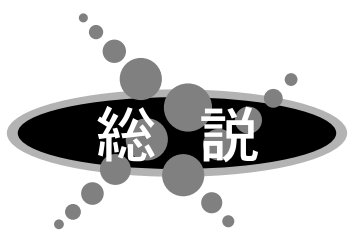

\title{
ヘルペスウイルスプロテアーゼの 活性制御機構と新なな阻害部位
}

\author{
味の素侏ライフサイエンス研究所 榛葉信久
}

\begin{abstract}
Kaposi's sarcoma-associated herpesvirus (KSHV), like all herpesviruses, encodes a protease (KSHV Pr), which is necessary for the viral lytic cycle. Herpesviral proteases function as obligate dimers, however, each monomer has an active site, which is spatially separate from the dimer interface. To address the potential of targeting the dimer interface, a 30 amino acid helical peptide was synthesized by protein grafting of an interfacial KSHV Pr $\alpha$ helix with a small stable protein, avian pancreatic polypeptide (aPP) to disrupt the dimerization of KSHV Pr. Biochemical analysis revealed that the rationally designed helical peptide inhibited KSHV Pr dimerization and activity. These results indicate that the dimer interface, as well as the active sites, of herpesvirus proteases is a viable target for inhibiting enzyme activity.
\end{abstract}

herpesvirus protease / Kaposi's sarcoma-associated herpesvirus / dimer / protein grafting

\section{1. はじめに}

ヘルペスウイルスは世界中で最も流行しているウイ ルスの1つであり, およそ 100 種類が確認されている. ヒトに感染するヘルペスウイルスのうち, 9つがさまざ まな病気とかかわって打り, 例えば, 疮疹や水疮瘡が あげられる。また，ヒトを重篤な病気に至らしめるも のとしてサイトメガロウイルスやカポシ肉腫ウイルス (Kaposi's sarcoma-associated herpesvirus; KSHV) が深刻 な問題となっている. 米国では1980年代にエイズ患者 へカポシ肉腫 (Kaposi's sarcoma; KS) が広がったが, エ イズ治療薬による効果も手伝い, 現在では減少傾向に ある ${ }^{1,2)}$. しかし, 最近では, アフリカに打けるカポシ 肉腫患者の数が大幅に増えている. 実際に, ウガンダ やジンバブエでは，男性のがんの第 1 位が，また女性 のがんの第 2 位がカポシ肉腫である ${ }^{3)}$.

すべてのヘルペスウイルスは, 配列のホモロジーの 高いプロテアーゼを有し, これがウイルスの増殖に必 須である. 約 $25 \mathrm{kDa}$ のプロテアーゼは, 別のタンパク 質と連結した形で発現する。このときプロテアーゼは 不活性な単量体であるが, ウイルスが球形になり，そ こに内包されると, 濃度の上昇に伴って 2 量体を形成 し活性体となる. その結果, プロテアーゼの作用によっ てウイルスが成熟体へと変形し，新たな細胞へと感染 していく(4)-6). それゆえ, ヘルペスウイルスプロテアー
ゼはドラッグターゲットとして考えられている7). ヘルペスウイルスプロテアーゼはセリンプロテ アーゼの 1 つであり, herpes simplex virus, VaricellaZoster virus, Epstein-Barr virus, human cytomegalovirus, KSHVが有するプロテアーゼの結晶構造が報告されてい る ${ }^{8)-15)}$. トリプシンに代表されるような消化酵素と比 べて 4 桁も触媒活性 $\left(k_{\mathrm{cal}} / K_{\mathrm{m}}\right)$ が低く, その 1 つの要因 として活性部位がSer-His-AspではなくSer-His-Hisであ ることがあげられている. 結晶構造はすべて 2 量体で あるが, 2 量体間の相互作用は弱く, 解離定数は $\mu \mathrm{M}$ オー ダーである ${ }^{16)-18)}$. また， 2 量体形成に伴って活性化す るにもかかわらず, 2 量体界面から離れた位置に活性部 位が存在する.

我々は，ヘルペスウイルスプロテアーゼの1つであ る KSHVプロテアーゼを題材として, 活性部位のセリ ン残基と 2 量体界面の関連を解析し, 2 量体形成に伴う 活性発現機構を明らかにした. 一方, 結晶構造から, へ ルペスウイルスの活性部位は非常に浅いポケットから なり, 特異的な阻害剤を設計することが困難であると 考えられた，実際にヘルペスウイルスプロテアーゼの 活性部位をターゲットとした阻害剤がいくつか報告さ れてきたが, いまだ医薬品になった例がない，そこで, 活性部位の代わりに, 2 量体形成を阻害するぺプチドを 設計し, プロテアーゼ活性を阻害できることを示した. 2 量体界面は非常に深いポケットで疎水的な残基が多い

\section{Regulating the Activity of the Herpesviral Protease and Its Viable Target for Inhibition Nobuhisa SHIMBA}

Ajinomoto Co., Institute of Life Sciences 


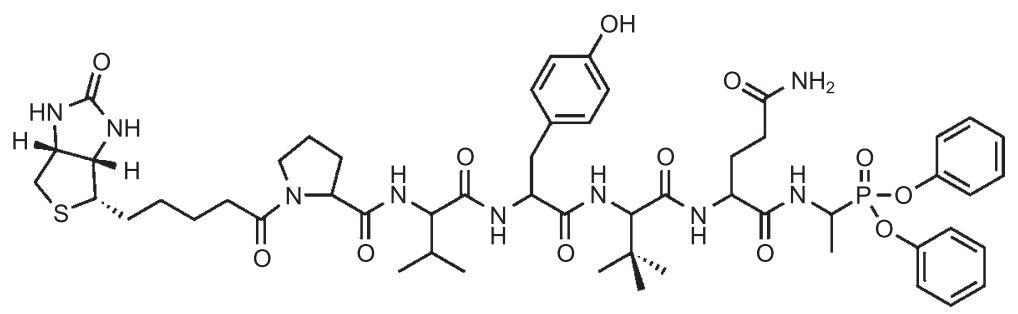

Fig. 1 Chemical structure of the optimized biotinyl-Pro-Val-Tyr-tBug-Gln-Ala $\mathrm{P}^{-}(\mathrm{OPh})_{2}$ inhibitor.

ことから, 特異的な阻害剤の開発に適していると考え られる. 今後, 2 量体界面をターゲットとした阻害剤の 開発により, 特異的にウイルスの増殖を防ぐことが期 待される．また，このように 1 つの分子の複数の部位 をターゲットとすることにより，耐性ウイルスの出現 を防ぐことができるかもしれない.

\section{2. 活性部位の阻害}

\section{1 プロテアーゼの基質特異性解析と遷移状態アナ ログ}

活性部位と2量体界面の相互作用を調べるために, 活 性部位に結合する阻害剤を作製した，リン酸基は遷移 状態を模倣していることから，基質に付加すると活性 部位のセリン残基を特異的に修飾し, 擬似的な遷移状 態を作り出すことができる ${ }^{19,20)}$. しかし，リン酸基の 特異性は低いので, 基質にはプロテアーゼ認識サイト を付加する必要がある. 天然の切断サイトが一例には なるが，最適とは限らないので，Craikらが開発した positional scanning synthetic combinatorial libraries (PSSCL) 21) を用いて, P1-P4サイトを決定した. 本方法では, 基質ペプチドの各サイトに20種のアミノ酸を導入した ライブラリーを作製し, プロテアーゼによって切断し やすい順を決めることができる，KSHVプロテアーゼ に適用したところ，P1サイトにはアラニン，P2サイト にはノルロイシン, P3サイトにはバリン, P4サイトに はチロシンが最適な残基であることが判明した．これ らのアミノ酸残基のうち, 溶解度を向上させるために ノルロイシンをグルタミン(ノルロイシンの約 $2 / 3$ の反 応性）へ置換し，また，P3サイトには，過去の知見 ${ }^{22}$ にもとづきバリンの代わりに tert-butylglycine 導入し た. さらに, 天然の基質の配列を参考にしてP5 サイト とP6サイトにそれぞれバリンとプロリンを加えた上で,

Fig. 1に示したようにリン酸基を付加することによって 基質アナログを合成した．このようなステップを経る ことによって, 特異性が高く, かつ溶解度の高い基質 アナログが設計できた.

まず，本化合物存在下においてKSHVプロテアーゼ
活性を追跡することにより，本化合物が不可逆的に結 合し活性を阻害していることを明らかにした ${ }^{23}$. 基質 アナログが結合した KSHVプロテアーゼは, あたかも 遷移状態でロックされた状態であり，ペプチド結合の 切断過程を的確に描写していると考元られる.

\section{2 活性阻害と2量体界面}

KSHVプロテアーゼにはメチオニン残基が 2 力所しか なく，そのうちの一方（Met197）は2量体界面に位置 している. 単量体と 2 量体の NMR シグナルを比較する と, 2 量体界面に位置するアミノ酸残基において異なる ことが予想される. そこで, KSHVプロテアーゼの 2 量 体形成を追跡する上で, Met197の NMR シグナルが指 標になると考えた. 特にメチオニン残基の側鎖メチル 基由来のシグナルの感度が良好であることを考慮して, メチオニン側鎖の ${ }^{13} \mathrm{C}$ 標識を行った。 その結果, KSHV プロテアーゼ単独のHSQCスペクトル上に, 3 個のピー クが観測された. Met197の改変や異なる濃度でのHSQC スペクトルを解析することによって,3個のピークのう ち2つは, それぞれ単量体と 2 量体の Met197 由来のシ グナルであることが判明した（Fig. 2)。つまり，NMR 測定を実施した濃度（約 $25 \mu \mathrm{M}$ ）では，KSHVプロテ アーゼは単量体と 2 量体の平衡状態にあることを示し ている. 続いて, 基質アナログを添加し, 遷移状態を 模做した状態にて同様な測定を行ったところ, 単量体 由来のシグナルが消失した（Fig. 2)，遷移状態を形成 する過程に打いて, KSHV プロテアーゼは強固な 2 量 体を形成することを意味する。活性部位は 2 量体界面 と約15オングストロームも離れているにもかかわらず, 基質アナログの結合に伴い分子間の相互作用が強化さ れ, 2 量体が安定化される. KSHVプロテアーゼの立体 構造からは, 界面に位置する $\alpha 5$ と触媒の 3 点セット （catalytic triad; 活性部位の Ser, His, His 残基）の間に直 接的な相互作用が見られていないことからも，驚くべ きことである。

遷移状態では, catalytic triad と, それが隣接するルー プ（Fig. 3b; loop）との相互作用を介して， $\alpha 6$ （Fig. 3b; $\alpha 6$ helix) へと構造変化が誘起される. $\alpha 6$ と $\alpha 5$ はペプチ 

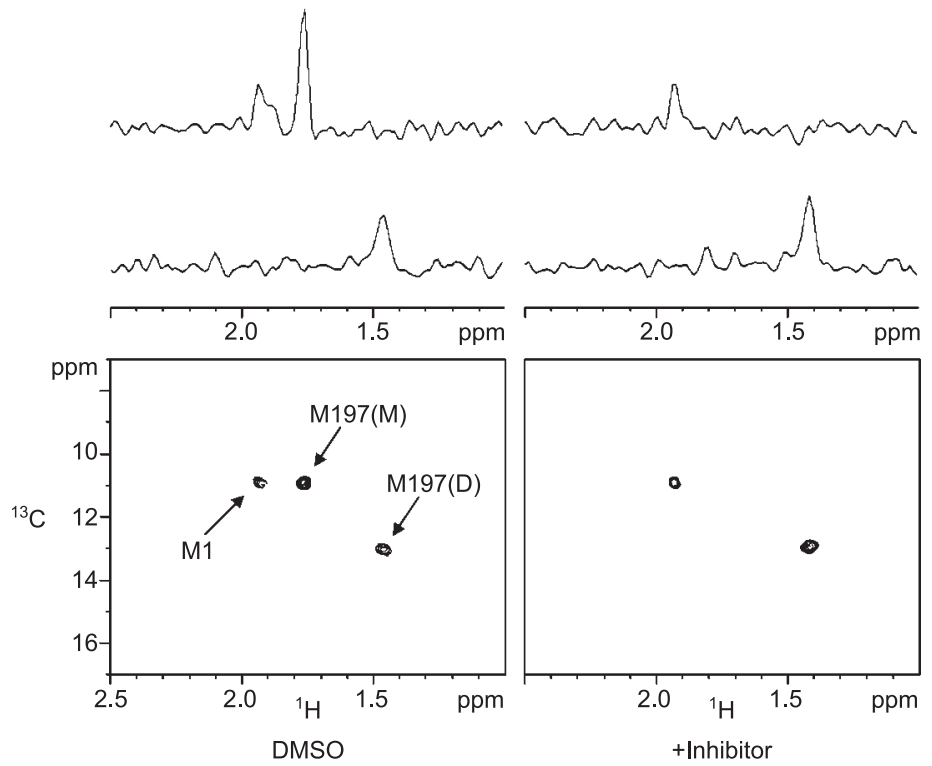

Fig. 2 Inhibition of KSHV Pr stabilizes the dimeric conformation. HSQC spectra of KSHV Pr labeled with methyl ${ }^{13} \mathrm{C}$ methionine after incubation with or without inhibitor. Signals reveal the solution oligomeric state of protease: M1, N terminus; Met197(M), monomer; Met197(D), dimer. 文献23（Marnett et al. PNAS）より転載.（カラー図は電子ジャーナルhttp:// www.jstage.jst.go.jp/browse/biophys/参照)

ド結合によって連結されているため, catalytic triadへ基 質類縁体が結合することによる影響が 05 へと伝達され ると考えられる.このような相互作用ネットワークが 形成された結果, $\alpha 5$ が安定化され, 分子間の相互作用 が強くなるのであろう，以上のように，KSHVプロテ アーゼの立体構造と, 基質アナログによって誘起され る2量体形成の安定化にもとづくと, KSHVプロテアー ゼの活性化には 2 量体形成が必須であり，その鍵とな るのは $\alpha 5$ や $\alpha 6$ の構造変化であることが推察された. 裏 返せば， $\alpha 5$ や $\alpha 6$ の構造変化を誘起しないようにすれ ば，活性部位から離れた 2 量体界面であっても KSHV プロテアーゼを阻害できると考えられる。しかしなが ら，今までに 2 量体界面を標的としてへルペスウイル スプロテアーゼの活性を阻害した例はない.

\section{2量体形成の阻害}

\subsection{2量体形成阻害ペプチドの設計}

KSHVプロテアーゼの 2 量体界面では, 一方の $\alpha 1$ と $\alpha 2$ が他方の $\alpha 5$ と相互作用している (Fig. 3b)．そこで, $\alpha 5$ の領域のみを模倣したぺプチドを設計する. $\alpha 5$ のみを 模倣したぺプチドは, $\alpha 1$ と $\alpha 2$ 領域をもたないため, 相 互作用した相手の分子の $\alpha 5$ が安定化されることはなく, プロテアーゼ活性阻害を引き起こすと推察される。本 研究ではそれを実証した。

まず， 2 量体形成を阻害するため，16残基のペプチ
ドを設計した（Fig. 3a). KSHVプロテアーゼの 2 量体 界面に存在する $\alpha 5$ の配列には, KSHVプロテアーゼに よる切断サイトが含まれているため, Ser13をグリシン へと置換し，KSHVプロテアーゼ中でもぺプチドが安 定に存在できるように工夫した $(\alpha 5$ ペプチドとよぶ). 対応する筒所に同様な置換（S204G/KSHV Pr）を導入 した変異体も, 野生型の KSHVプロテアーゼと同じよ うに 2 量体化するため, セリンからグリシンへの置換 によって相互作用様式の大きな変化は引き起こされな (17). しかしながら， $\alpha 5$ ペプチド単独では溶液中で $\alpha$ ヘリックスを形成することはない．より強く相互作用 させるためには， $\alpha$ へリックス構造を保持するように 設計し, KSHVプロテアーゼと相互作用させる際に $\alpha$ へ リックスを形成する必要性をなくすことが望ましい.

そこで, プロテイングラフティング*によって $\alpha へ$ リックスを形成させた上で，KSHVプロテアーゼの相 互作用界面を模倣したぺプチドを設計した。 avian pancreatic polypeptide (aPP) は, 36残基の小さい分子にも かかわらず安定なタンパク質であり， $\alpha$ ヘリックスが polyproline helix との相互作用によって安定化されてい $3^{24)}$. しかも, aPP 分子の一方の面のみが $\alpha$ ヘリック スの安定化に関与しており, 溶媒へ露出している残基 に関してはKSHVプロテアーゼの $\alpha 5$ を模做するように 置換することが可能である ${ }^{25)}$. そこで, KSHVプロテ アーゼの立体構造にもとづき，相互作用に重要な 9 残 
基を選択し（Fig. 3a），aPPへと導入した. このぺプチ ドをKSaPPとよぶ.

続いてKSHVプロテアーゼとKSaPPの複合体のモデ ル構造を構築したところ, Asn29, Thr32, C 末端の側 鎖が立体障害となることが推測された (Fig. 3c).さら に, aPPのC末端は無秩序な構造であり, $\alpha$ ヘリックス の形成に必須ではない. その結果, Asn29をグリシンへ 置換することに加え, N末端Gly1 とC 末端Thr32-Tyr36 を削除し，30残基のペプチド（KSDDペプチド）を設 計するに至った。

円二色性 $(\mathrm{CD})$ 測定の結果, $\alpha 5$ ペプチドは $\alpha$ ヘリッ クスを形成していないことが示された.一方, KSDDぺ プチドは， $\alpha$ ヘリックスを含有するタンパク質に典型
的なスペクトルを与えた. $\alpha$ ヘリックスの含有量を見 積もったところ，約 40\%であり，すでに報告されてい

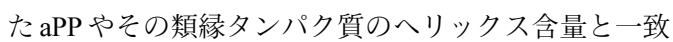
することがわかった ${ }^{26)}$. 以上の結果, プロテイングラ フティングによって設計した KSDD ペプチドは， $\alpha$ へ リックスを形成していることが判明した。

\section{2 活性阻害と阻害様式}

$\alpha 5$ ペプチドとKSDDペプチドそれぞれを添加した上 で, KSHVプロテアーゼの活性を測定した. プロテアー ゼと基質の濃度を固定し, 両ぺプチドの濃度を変化さ せることによって得られた阻害曲線を Fig. 4 に示す. $\alpha 5$ ペプチドはKSHVプロテアーゼより 400 倍も高い濃度 でも阻害活性を示さなかった一方, KSDDぺプチドは,

(a)

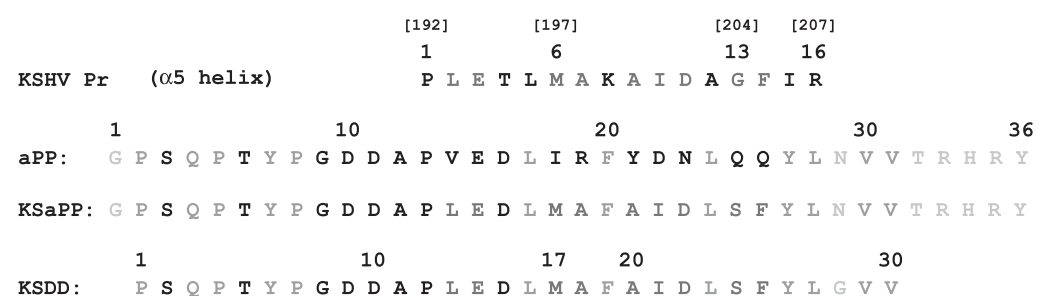

(b)

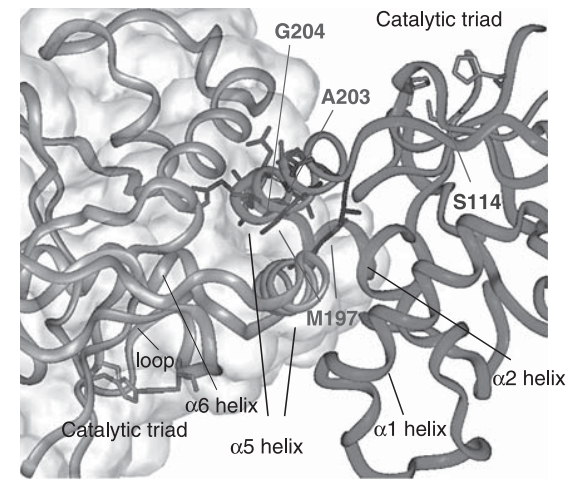

(c)

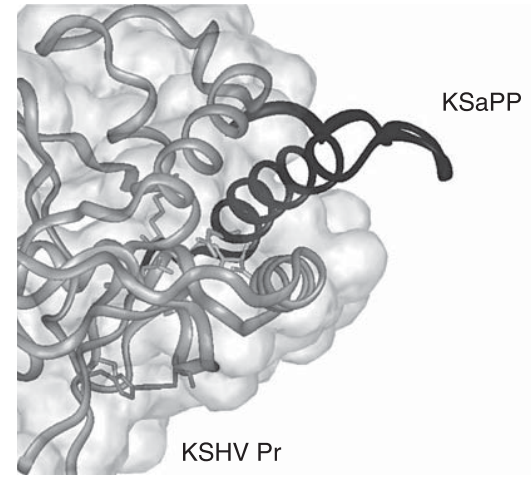

Fig. 3 Strategy for the design of the KSDD peptide. (a) Sequence alignment of aPP and the $\alpha 5$ helix in KSHV Pr, and designed sequences of the KSaPP and KSDD peptides. Specific residue numbers are given above peptide sequences, and the corresponding residue numbers in KSHV Pr are given in parentheses. The nine residues (Leu193, Glu194, Met197, Ala198, Ala200, Ile201, Asp202, Gly204, Phe205) in the $\alpha 5$ helix of one monomer of KSHV Pr interact with the second monomer of KSHV Pr. Residues, Pro2, GIn4, Pro5, Tyr7, Pro8, Leu17, Phe20, Leu24, Tyr27, Leu28, Val30, and Val31, in the aPP sequence are required for stabilizing the helical structure. Based on the model structure of the KSHV Pr-KSaPP complex (panel c), conflicting or functionally unnecessary residues in KSaPP are expected to be Gly1, Asn29, Thr32-Tyr36. The mutation site for attenuation of autolysis is Gly 13 in the $\alpha 5$ peptide. (b) Dimer interface in the crystal structure of KSHV Pr. (c) A model structure of the KSHV Pr-KSaPP peptide complex was constructed by replacing the $\alpha 5$ helix in one monomer of KSHV Pr with aPP. Formation of the hydrophobic aPP core requires residues on only one face of the $\alpha$-helix. The opposite, solvent-exposed face of the $\alpha$-helix is available for recognition of KSHV Pr; these residues interact with the other monomer. A combined sequence was generated and referred to as KSaPP. The wild-type KSHV Pr serine residue was reintroduced at the position of Gly13 in the KSaPP peptide because the autolysis site present in KSHV Pr and the $\alpha 5$ peptide no longer exists in KSaPP. The KSDD peptide was finally designed by replacing Asn29 with a glycine and by removing Gly1 and Thr32 through Tyr36. (カラー図は電子ジャーナルhttp:// www.jstage.jst.go.jp/browse/biophys/参照) 


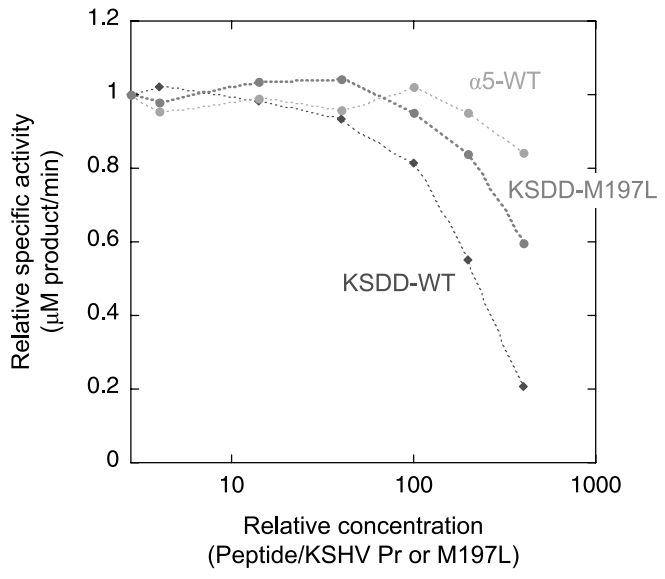

Fig. 4 Peptide concentration dependence of KSHV Pr specific activity. The KSDD peptide inhibits KSHV Pr (filled diamonds) or KSHV Pr M197L (filled circles) activity by $50 \%$ at a $\sim 200$ - or 400 -fold molar excess of peptide over KSHV Pr or KSHV Pr M197L, respectively. In contrast, the $\alpha 5$ peptide did not inhibit KSHV $\mathrm{Pr}$ activity at concentrations up to 400 -fold higher than KSHV Pr concentrations (gray circles). 文献 27 （Shimba et al. J. Virol.）より転載.（カラー図は電子 ジャーナル http://www.jstage.jst.go.jp/browse/biophys/参 照）

濃度依存的に KSHV プロテアーゼ活性を阻害した。

Fig. 4からは, KSHVプロテアーゼに対し約200倍のペプ チドを添加することによって, 活性が $50 \%$ と低下す ることがわかる. また, 2 量体形成阻害に伴って活性が 阻害されていることを確認するために, ゲルろ過力ラ ムによる分析も実施した，その結果，KSDDぺプチド 存在下に拈いてKSHVプロテアーゼが単量体化してい ることが判明した.

さらに, KSDD が 2 量体形成界面と相互作用してい ることを確認するため, KSHVプロテアーゼの変異体 を作製した， 2 量体界面の残基を置換した変異体では, KSDD ペプチドの効果が異なることを示す. まず, 2 量 体界面の相互作用を変化させることを目的とし, 立体 構造にもとづきいくつかの変異体を設計したところ, M197Lでは分子間の相互作用がより強くなり, 2 量体が 安定化していることが判明した. Met197は2量体界面 に位置し, もう一方の分子のMet197と相互作用してい るので, これらをロイシンに置換することによって相 互作用が強くなったと考えられる. この変異体は, 2 量 体界面の残基が置換されているにもかかわらず, 2 量体 を形成する能力を有しているので, 活性を指標として 2 量体形成阻害剤の効果を比較することができる. KSDD ペプチド存在下において，M197L 変異体の活性を測
定したところ，活性を 50\%へ低下させるには，約 400 倍のKSDDぺプチドが必要であることがわかった (Fig. 4).これは, 野生型の場合の約 2 倍である. 2 量 体界面を置換した変異体と野生型ではKSDDぺプチド の効果が異なることは，2 量体界面に結合するように KSDD ププチドを設計した背景と矛盾していない.

\section{4. まとめ}

酵素の活性部位の阻害は非常に魅力的ではあるが, KSHVプロテアーゼのように活性部位が浅い谷間である 場合には困難を伴う。また, ウイルスの増殖を防ぐこ とを目的とするときには, かならず耐性株の出現に配 慮する必要があり, ターゲットタンパク質の複数の部 位を阻害することは医薬品開発には有望な手段である. 我々は, ヘルペスウイルスの増殖に欠かせないプロテ アーゼを題材として, 活性部位から空間的に離れた位 置にある 2 量体界面をターゲットとして, プロテアー ゼ活性を阻害することに成功した.つまり，2 量体界面 も活性部位と同じようにヘルペスウイルスプロテアー ゼを阻害する上でターゲットとなり得ることを証明し た. ヘルペスウイルスプロテアーゼの 2 量体形成阻害 によって選択性高くウイルスの増殖を抑制できる可能 性があり, 感染を防ぐ上で貴重な知見となるであろ j $^{27)}$.

\section{謝 辞}

本稿にて紹介した研究は, Charles S. Craik教授, Anson M. Nomura 博士, Alan B. Marnett博士 (カリフォルニア 大学サンフランシスコ校）との共同研究によるもので す.また, 鈴木榮一郎理事 (味の素(陎) には多くの助 言を頂きました。この場を借りて感謝申し上げます.

\section{文 献}

1) Parisi, S. G., Mazzi, R., Sarmati, L., Carolo, G., Uccella, I., Rianda, A., Nicastri, E., Concia, E. and Andreoni, M. (2002) AIDS 16, 1089-1091.

2) Tam, H. K., Zhang, Z. F., Jacobson, L. P., Margolick, J. B., Chmiel, J. S., Rinaldo, C. and Detels, R. (2002) Int. J. Cancer 98, 916-922.

3) Dedicoat, M. and Newton, R. (2003) Br. J. Cancer 88, $1-3$.

4) Welch, A. R., Woods, A. S., McNally, L. M., Cotter, R. J. and Gibson, W. (1991) Proc. Natl. Acad. Sci. USA 88, 10792-10796.

5) Weinheimer, S. P., McCann, P. J., III, O’Boyle, D. R., II, Stevens, J. T., Boyd, B. A., Drier, D. A., Yamanaka, G. A., DiIanni, C. L., Deckman, I. C. and Cordingley, M. G. (1993) J. Virol. 67, 5813-5822.

6) Sheaffer, A. K., Newcomb, W. W., Brown, J. C., Gao, M., Weller, S. K. and Tenney, D. J. (2000) J. Virol. 74, 6838- 
6848.

7) Waxman, L. and Darke, P. L. (2000) Antiviral Chem. Chemother. 11, 1-22.

8) Chen, P., Tsuge, H., Almassy, R. J., Gribskov, C. L., Katoh, S., Vanderpool, D. L., Margosiak, S. A., Pinko, C., Matthews, D. A. and Kan, C. C. (1996) Cell 86, 835-843.

9) Tong, L., Qian, C., Massariol, M. J., Bonneau, P. R., Cordingley, M. G. and Lagacé, L. (1996) Nature 383, 272275.

10) Shieh, H. S., Kurumbail, R. G., Stevens, A. M., Stegeman, R. A., Sturman, E. J., Pak, J. Y., Wittwer, A. J., Palmier, M. O., Wiegand, R. C., Holwerda, B. C. and Stallings, W. C. (1996) Nature 383, 279-282.

11) Qiu, X., Culp, J. S., DiLella, A. G., Hellmig, B., Hoog, S. S., Janson, C. A., Smith, W. W. and Abdel-Meguid, S. S. (1996) Nature 383, 275-279.

12) Qiu, X., Janson, C. A., Culp, J. S., Richardson, S. B., Debouck, C., Smith, W. W. and Abdel-Meguid, S. S. (1997) Proc. Natl. Acad. Sci. USA 94, 2874-2879.

13) Reiling, K. K., Pray, T. R., Craik, C. S. and Stroud, R. M. (2000) Biochemistry 39, 12796-12803.

14) Hoog, S. S., Smith, W. W., Qiu, X., Janson, C. A., Hellmig, B., McQueney, M. S., O’Donnell, K., O'Shannessy, D., DiLella, A. G., Debouck, C. and Abdel-Meguid, S. S. (1997) Biochemistry 36, 14023-14029.

15) Buisson, M., Hernandez, J. F., Lascoux, D., Schoehn, G., Forest, E., Arlaud, G., Seigneurin, J. M., Ruigrok, R. W. and Burmeister, W. P. (2002) J. Mol. Biol. 324, 89-103.
16) Buisson, M., Valette, E., Hernandez, J. F., Baudin, F., Ebel, C., Morand, P., Seigneurin, J. M., Arlaud, G. J. and Ruigrok, R. W. (2001) J. Mol. Biol. 311, 217-228.

17) Pray, T. R., Nomura, A. M., Pennington, M. W. and Craik, C. S. (1999) J. Mol. Biol. 289, 197-203.

18) Cole, J. L. (1996) Biochemistry 35, 15601-15610.

19) Sampson, N. S. and Bartlett, P. A. (1991) Biochemistry 30, 2255-2263.

20) Oleksyszyn, J. and Powers, J. C. (1991) Biochemistry 30, 485-493.

21) Harris, J. L., Backes, B. J., Leonetti, F., Mahrus, S., Ellman, J. A. and Craik, C. S. (2000) Proc. Natl. Acad. Sci. USA 97, 7754-7759.

22) Ogilvie, W., Bailey, M., Poupart, M. A., Abraham, A., Bhavsar, A., Bonneau, P., Bordeleau, J., Bousquet, Y., Chabot, C., Duceppe, J. S. et al. (1997) J. Med. Chem. 40, 4113-4135.

23) Marnett, A. B., Nomura, A. M., Shimba, N., Mahrus, S., Ortiz de Montellano, P. R., and Craik, C. S. (2004) Proc. Natl. Acad. Sci. USA 101, 6870-6875.

24) Glover, I., Haneef, I., Pitts, J., Wood, S., Moss, D., Tickle, I., and Blundell, T. (1983) Biopolymers 22, 293-304.

25) Zondlo, N. J. and Schepartz, A. (1999) J. Am. Chem. Soc. 121, 6938-6939.

26) Noelken, M. E., Chang, P. J. and Kimmel J. R. (1980) Biochemistry 19, 1838-1843.

27) Shimba, N., Nomura, A. M., Margnett, A. B. and Craik, C. S. (2004) J. Virol. 78, 6657-6665. 


\section{ヘルペスウイルスプロテアーゼの活性制御機構と新たな阻害部位}

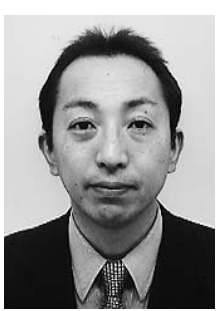

榛葉信久（しんば のぶひさ）

味の素秼ライフサイエンス研究所研究員

1998 年東京大学大学院薬学系研究科修了 (薬学博士), 98-02 年味の素(侏中央研究所研究員, 02-04 年UCSF 博 士研究員, 04 年より現職へ。

研究内容 : タンパク質の立体構造解析とその情報にもとづくタンパク質工学やリガンド設計

連絡先：干210-8681 神奈川県川崎市川崎区鈴木町 1-1

E-mail: nobuhisa_shimba@ajinomoto.com

溙葉信久 